Jurnal SEMAR Vol. 9 No. 1, hal. $13-18$

\title{
PEMBERDAYAAN KAUM IBU MELALUI PROGRAM “ROEMAH IBU” DI KABUPATEN WONOGIRI
}

\author{
Yesiana Arimurti ${ }^{1} \mid$ Sri Budiawanti $^{1} \mid$ Nonoh Siti Aminah ${ }^{1}$ \\ ${ }^{1}$ Program Studi Pendidikan Fisika, FKIP \\ Universitas Sebelas Maret, Surakarta
}

\begin{abstract}
Abstrak
Perempuan merupakan tonggak peradaban. Ia adalah sekolah pertama bagi anak-anaknya. Jika baik ibunya, maka kemungkinan lahir generasi yang baik akan meningkat. Namun, kaum perempuan masih sering dianggap sebagai "kanca wingking" yang berarti hanya sekadar mengurus pekerjaan domestik di rumah sehingga seringkali kurang berdaya. Tak terkecuali di wilayah kecamatan Wonogiri, kabupaten Wonogiri, masih banyak ibu-ibu rumah tangga yang belum mengoptimalkan potensinya. Program "Roemah Ibu" merupakan sebuah upaya pemberdayaan kaum ibu, melalui program-program pelatihan dan pendampingan. Pelatihan yang dirancang antara lain: pelatihan pembuatan tas rajut, pelatihan pembuatan sabun organik, dan pendampingan pemasaran produk. Saat ini beberapa ibu rumah tangga telah mampu menjual karya tas rajutnya dengan kisaran harga Rp60.000,00 hingga Rp 300.000,00/tas.
\end{abstract}

Kata kunci: pelatihan, pendampingan, pemberdayaan perempuan, roemah ibu.

\section{Pendahuluan}

Kaum perempuan atau kaum ibu memerankan peran yang sangat penting dalam pembangunan peradaban. Ibu merupakan sekolah pertama bagi anak-anaknya, pembentuk akhlak, dan karakter kepribadian anak sebelum anak terpapar oleh pengaruh lingkungan. Ibu memberikan pondasi bagi pembangunan karakter anak. Selain itu ibu juga seringkali ikut menopang kesejahteraan rumah tangga. Namun demikian, masih banyak juga yang beranggapan bahwa perempuan hanyalah "kanca wingking" yang berarti hanya berkutat dengan urusan pekerjaan rumah tangga sehingga belum mampu berdaya atau memaksimalkan potensinya.

Program pemberdayaan kaum perempuan atau kaum ibu semakin gencar digalakkan oleh pemerintah. Selain peran pemerintah, pemberdayaan perempuan berbasis komunitas juga semakin marak dan mampu menghasilkan ibu-ibu yang berdaya. Peran perguruan tinggi melalui tri dharma perguruan tinggi cukup signifikan dalam upaya memberdayakan kaum perempuan. Harapannya, dengan perempuan yang berdaya, kesejahteraan dan ketentraman keluarga akan meningkat.

Kabupaten Wonogiri merupakan sebuah kabupaten yang termasuk dalam wilayah Propinsi Jawa Tengah, berbatasan langsung dengan D.I. Yogyakarta dan Propinsi Jawa Timur. Kabupaten Wonogiri terdiri dari 26 kecamatan. Kondisi gografis kabupaten Wonogiri sangat beragam. Mulai dari dataran rendah (Wonogiri kota, Ngadirojo, Sidoharjo, Jatisrono, Slogohimo, Puwantoro, Kismantoro Wuryantoro, Eromoko, Manyaran,dll), dataran tinggi (Karangtengah, Bulukerto, Puhpelem), daerah kars dan pesisir pantai (Paranggupito). Menurut data dari Badan Pusat Statistik Kabupaten Wonogiri, persentase perempuan yang menamatkan sekolah pada tahun 2014 jenjang SD sebesar 30,23 \%, jenjang SMP sebesar 17,57 \%, jenjang SMA 12,6 \%, dan jenjang perguruan tinggi sebesar 4,07 \%. Persentase ini menunjukkan bahwa perempuan di kabupaten Wonogiri sebagain besar berpendidikan tamatan Sekolah Dasar. Meskipun pendidikan formal tidak bisa menjadi acuan dasar bahwa seorang perempuan mampu berdaya dan mandiri secara ekonomi atupun tidak, namun data ini paling tidak menunjukkan bahwa masih banyak perempuan yang kurang berdaya dikarenakan tingkat pendidikan yang rendah. 
Jurnal SEMAR Vol. 9 No. 1 , hal. $13-18$

Jumlah perempuan dengan usia di atas 15 tahun yang berkegiatan mengurus rumah tangga atau ibu rumah tangga di kabupaten Wonogiri sejumlah 123.459 orang. Ini merupakan jumlah yang cukup besar. Jika ibu-ibu rumah tangga ini mampu diberdayakan untuk berwirausaha di rumah, kesejahteraan keluarga dimungkinkan akan mengalami peningkatan.

Berdasarkan data, latar belakang dan analisis yang telah diuraikan, penulis menyelenggarakan program pengabdian kepada masyarakat berupa pemberdayaan kaum ibu berbasis komunitas melalui program "Roemah Ibu". "Roemah Ibu" merupakan wadah bagi para ibu untuk meningkatkan keterampilan, merintis kegiatan wirausaha, dan meningkatkan wawasan global. Melalui program ini, diharapkan kaum ibu dapat lebih berdaya, memiliki pengetahuan luas, dan berperan aktif dalam peningkatan kesejahteraan keluarga.

\section{Metode Pelaksanaan}

Kegiatan pengabdian ini dilaksanakan di lingkungan Bulusari RT 01 Rw 05 Wonoboyo, Kecamatan Wonogiri, Kabupaten Wonogiri dengan mitra ibu-ibu rumah tangga di lingkungan tersebut. Kegiatan pengabdian dilaksanakan dengan metode pelatihan dan pendampingan pemasaran produk. Evaluasi kegiatan dilakukan dengan observasi, wawancara, dan angket.

\section{Hasil dan Pembahasan}

Telah dibentuk sebuah wadah komunitas yang memfasilitasi ibu-ibu rumah tangga di wilayah Bulusari RT 2 RW 5, Bulusulur, kecamatan Wonogiri, Kabupaten Wonogiri yang kemudian disebut Roemah Ibu. Roemah ibu merupakan tempat untuk usaha peningkatan ketrampilan dan pengetahuan bagi kaum ibu dan harapannya dapat meningkatkan kesejahteraan kaum ibu. Di lingkungan sekitar lokasi Roemah Ibu, sebagian warga berprofesi sebagai wiraswasta atau pedagang dengan komoditas mayoritas makanan. Roemah Ibu menjadi tempat bagi kaum ibu untuk mengembangkan keterampilan dan mengembangan komoditas perdagangan selain makanan. Selain peningkatan kesejahteraan ekonomi kaum ibu, roemah ibu juga direncanakan akan berperan sebagai wadah peningkatan pengetahuan kaum ibu melalui kegiatan seperti belajar membaca Al Quran, seminar parenting dan lain-lain.

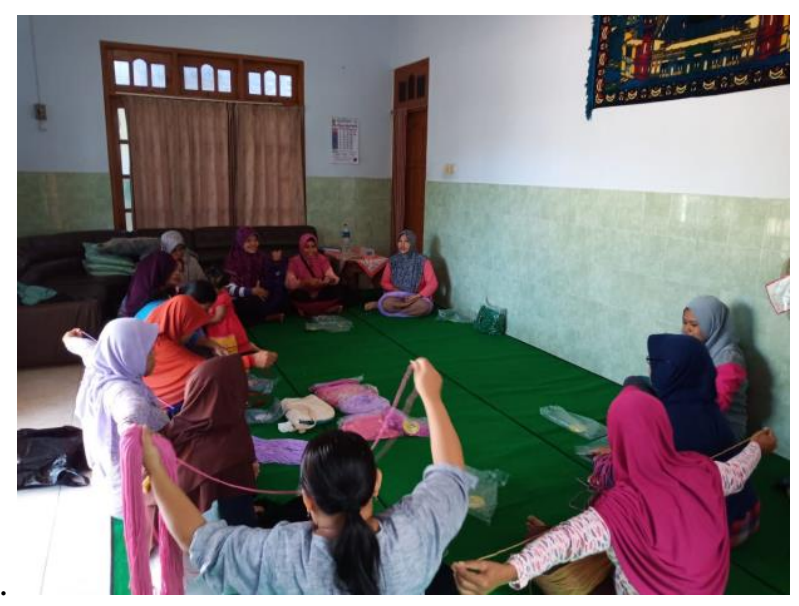

Gambar 1. Kegiatan pelatihan pembuatan tas rajut di Roemah Ibu.

Kegiatan pemberdayaan kaum ibu melalui program Roemah Ibu telah terlaksana dua kegiatan pelatihan yaitu pembuatan tas rajut dan pelatihan pembuatan sabun alami. Kegiatan pelatihan pembuatan tas rajut diikuti oleh sekitar 21 peserta ditunjukkan oleh Gambar 1. Ibu-ibu di daerah Bulusari RT 2 RW 5, terlihat sangat antusias dalam mengikuti pelatihan dan bersemangat untuk mengembangkan produk serta memasarkan hasil karyanya. Sampai saat ini, pemasaran produk tas rajut masih terbatas pada 
beberapa kalangan di lingkungan sekitar Roemah Ibu dan hanya berdasarkan pesanan. Untuk memperluas jaringan pemasaran, tim pengabdi melakukan pendampingan dengan cara memberi alternatif sarana pemasaran produk dengan penjualan daring (online) melalui media WhatsApp dan Instagram Story dengan masih menggunakan akun tim pengabdi sebagaimana terlihat pada Gambar 2.

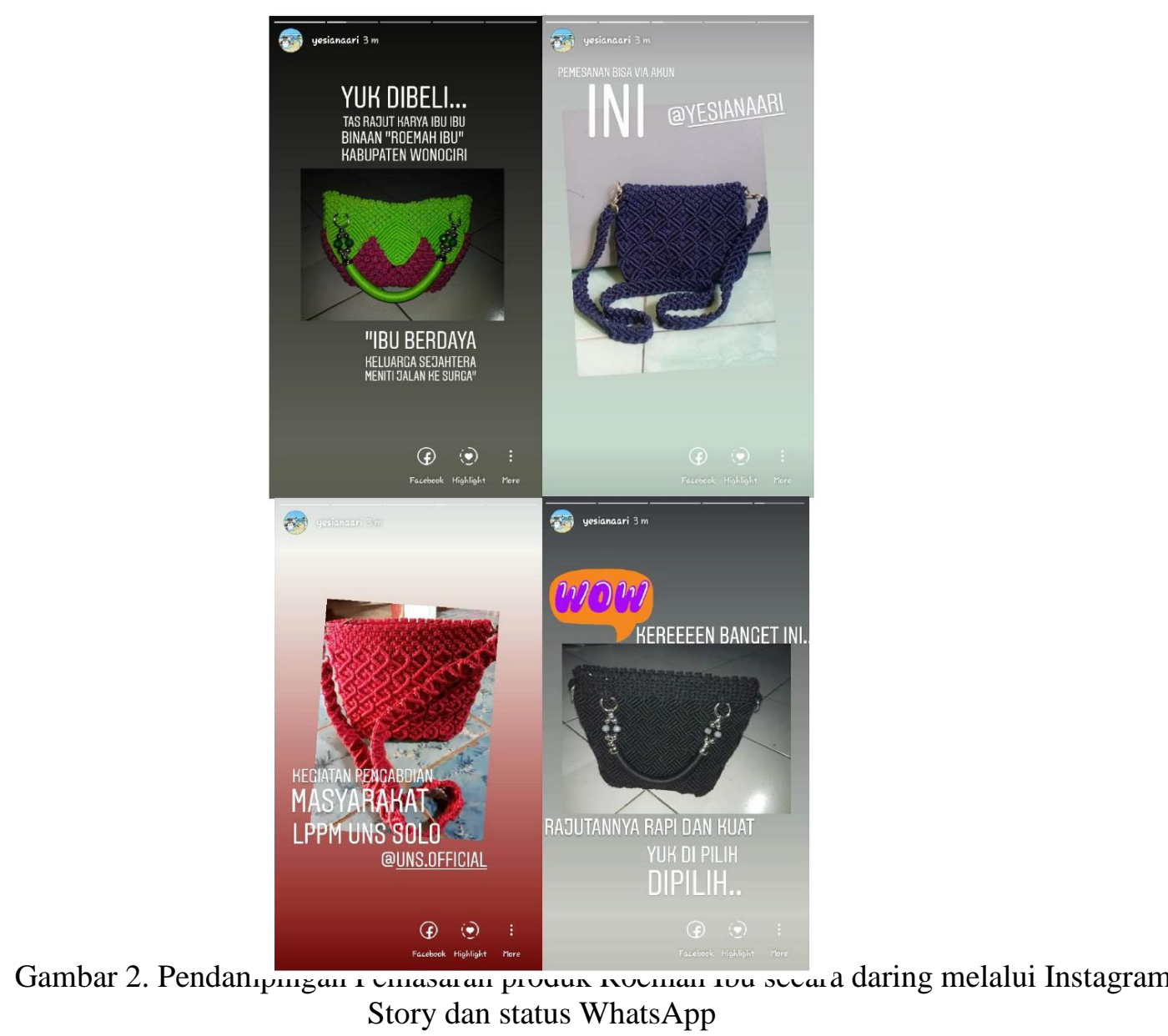

Selanjutnya, tim pengabdi melaksanakan kegiatan penyuluhan / pelatihan pembuatan sabun homemade dengan metode Melt and Pour dan ditambah bahan alami seperti bubuk kopi, serai, minyak zaitun, dan lain-lain. Selain bisa digunakan sendiri, sabun homemade ini juga dapat dijual kembali secara eceran atau bisa dijadikan souvenir. Tim pengabdi menyediakan bahan dasar sabun dan beberapa bahan tambahan lain seperti essential oil kopi dan lemon serta bubuk sari jus lemon untuk dapat digunakan peserta pelatihan mencoba dan mengembangkan produknya. Pelatihan ini diikuti sebanyak 9 peserta ibu-ibu di wilayah Bulusari RT 02 RW 05 Wonoboyo, Wonogiri. Peserta nampak sangat antusias dengan kegiatan ini seperti pada Gambar 3 dan 4. Bahkan ada memiliki kulit sensitif dan sangat tertarik dengan sabun alami ini karena bahan dasar sabun ini tidak mengandung bahan yang membuat kulit kering seperti halnya sabun yang biasa dijual dipasaran. 
Jurnal SEMAR Vol. 9 No. 1, hal. $13-18$

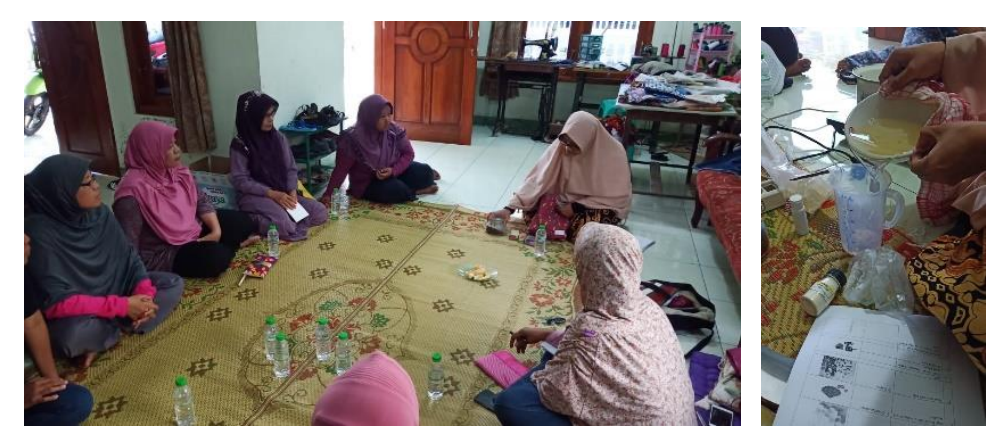

Gambar 3. Kegiatan pelatihan pembuatan sabun alami di Roemah Ibu (kiri) Pendampingan pembuatan sabun alami di Roemah Ibu (kanan)

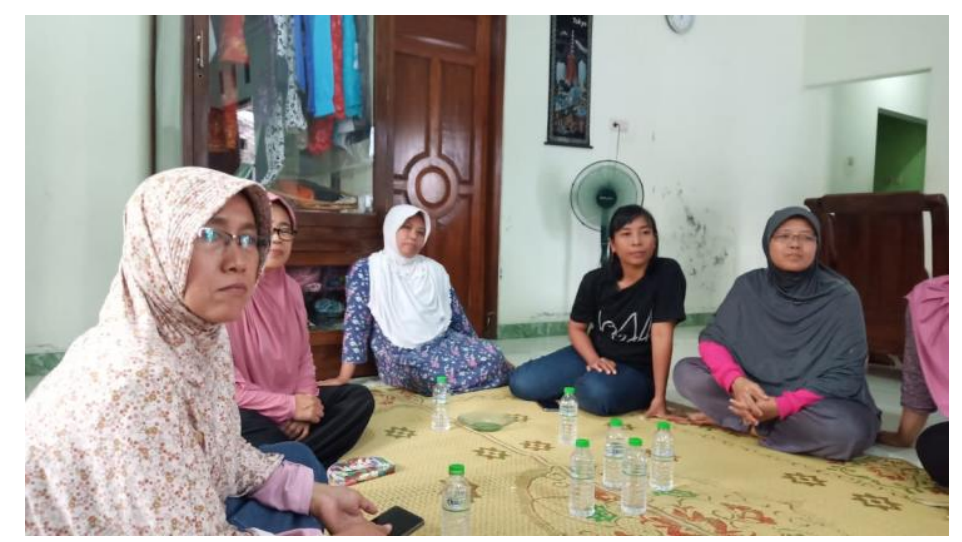

Gambar 4. Peserta pelatihan pembuatan sabun alami di Roemah Ibu.

Saat ini telah dihasilkan beberapa produk tas rajut seperti pada Gambar 5 dan 6. Tas tersebut telah dijual berdasarkan pesanan. Hingga saat ini beberapa ibu rumah tangga telah menerima pesanan tas rajut secara konsisten. Harga jual tas beragam sesuai ukuran tas, mulai daro Rp 60.000,00 hingga Rp $300.000,00$.
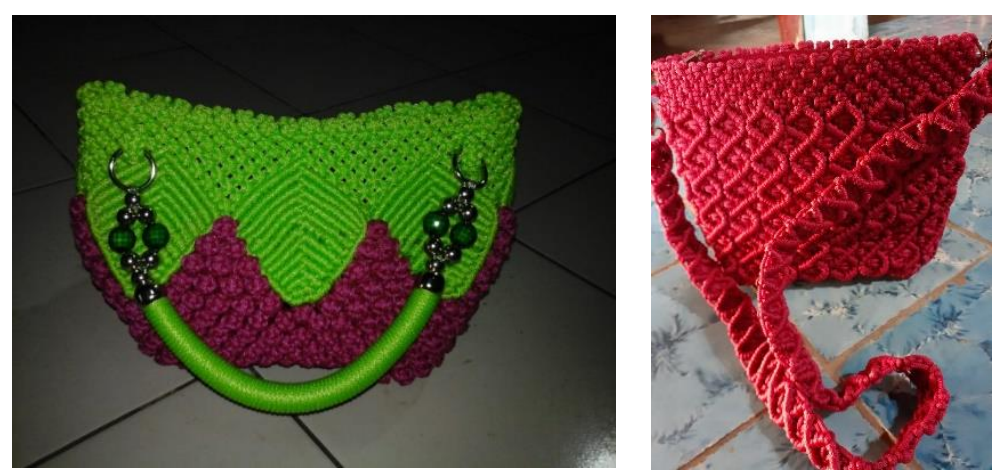

Gambar 5. Foto produk ras rajut strawbery, ukuran lebar $27 \mathrm{~cm}$, tinggi $20 \mathrm{~cm}$. Dijual dengan harga Rp 300.000,00 (kiri). Foto produk ras rajut ulir. Dijual dengan harga Rp 165.000,00 (kanan) 

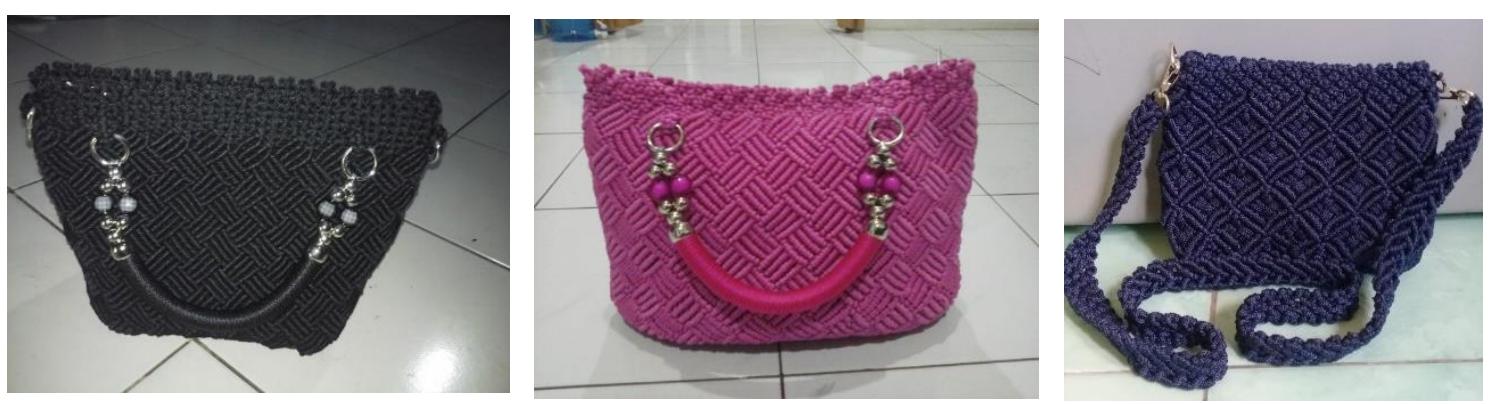

Gambar 6. Foto produk ras rajut anyaman hitam, ukuran lebar $28 \mathrm{~cm}$, tinggi $21 \mathrm{~cm}$. Dijual dengan harga Rp $250.000,00$ (kiri) Foto produk ras rajut anyaman pink, ukuran lebar $28 \mathrm{~cm}$, tinggi $21 \mathrm{~cm}$. Dijual dengan harga Rp 250.000,00 (tengah) Foto produk ras rajut kecil motif papan catur. Dijual dengan harga Rp 60.000,00

(kanan).

\section{Evaluasi Program Roemah Ibu}

Evaluasi program Roemah Ibu dilakukan dengan observasi dan pengisian angket. Berdasarkan hasil observasi, ibu-ibu warga lingkungan Bulusari RT 02 RW 05, Wonoboyo, Wonogiri, sangat antusias dengan kegiatan yang dilaksanakan di Roemah Ibu. Terbukti dari banyaknya peserta yang hadir pada kegiatan pelatihan yang diadakan di Roemah Ibu. Serta besarnya harapan warga agar Roemah Ibu lebih sering mengadakan pertemuan atau pelatihan ketrampilan.

Pengisian angket dilakukan setelah kegiatan pelatian pembuatan sabun alami. Pelatihan ini merupakan pelatihan lanjutan dari serangkaian kegiatan pengabdian di Roemah Ibu. Sehingga, peserta yang mengikuti pelatihan ini dipilih hanya ibu-ibu yang mudah digerakkan dan yang memiliki semangat belajar ketrampilan baru. Harapannya setelah kegiatan ini, ibu-ibu yang dipilih ini dapat menyalurkan ilmu kepada warga secara lebih luas. Berdasarkan hasil wawancara, peserta pada pelatihan kedua ini akan memabagikan ilmu yang diperoleh dari pelatihan pembuatan sabun alami ini di kegiatan arisan dasa wisma dan arisan PKK di lingkungan setempat.

Berdasarkan hasil angket, dari 9 ibu, 67\% sangat mengenal Roemah ibu. Sisanya 33\% menyatakan hanya mengenal Roemah Ibu. 78\% ibu sangat merasakan manfaat dari program Roemah Ibu. Roemah ibu juga diharapkan bisa menjadi inisiator dan inkubator wirausaha bagi ibu-ibu di lingkungan setempat. Hal ini telah tercapai sebagaimana berdasarkan hasil angket 56\% ibu merasa sangat bisa memulai usaha dari kegiatan-kegiatan yang dilaksanakan di Roemah Ibu. Dengan demikian, Roemah Ibu dipandang mampu meningkatkan kualitas hidup kaum ibu. Sedangkan dari segi variasi kegiatan, $56 \%$ ibu menyatakan bahwa kegiatan di Roemah Ibu sangat variatif dan menyenangkan. Dan akhirnya 67\% ibu menyatakan bahwa keberadaan Roemah Ibu sangat berarti bagi lingkungan setempat. Beberapa saran kegiatan juga diusulkan oleh peserta pelatihan, antara lain:

1. Pengajian/ kajian agama

2. Memperbanyak pelatihan ketrampilan

3. Pelatihan wirausaha

4. Pelayanan/ penyuluhan kesehatan

5. Pengadaan perpustakaan.

\section{Penutup}

Berdasarkan observasi, wawancara, dan hasil angket, kegiatan Roemah Ibu sangat memberikan manfaat bagi warga di linkungan Bulusari RT 02 RW 05 Wonoboyo, Wonogiri. Kini ibu-ibu rumah tangga ini memiliki ketrampilan tambahan selain mengurus rumah tangga, yaitu membuat tas rajut dan sabun alami. Beberapa ibu rumah tangga sudah konsisten mendapat pesanan tas rajut sehingga mampu menambah pendapatan keluarga. Sedangkan ketrampilan membuat sabun alami membuat ibu-ibu 
Jurnal SEMAR Vol. 9 No. 1, hal. $13-18$

ISSN: 2302-3937 | Copyright @ LPPM Universitas Sebelas Maret

Homepage: https://jurnal.uns.ac.id/jurnal-semar

rumah tangga ini lebih mengerti konsep kesehatan keluarga dan berusaha memberi yang terbaik untuk seluruh anggota keluarga dengan membuat sabun sendiri yang lebih menyehatkan kulit.

\section{Referensi}

BPS, W. (2016, February 26). Pendidikan : BPS Wonogiri. Retrieved April 25, 2019, from BPS Wonogiri web site: https://wonogirikab.bps.go.id/statictable/2015/12/14/158/pendidikan-yangditamatkan-2014.html

BPS, W. (2016, February 26). Tenaga Kerja: BPS Wonogiri. Retrieved April 25, 2019, from BPS Wonogiri Web site: https://wonogirikab.bps.go.id/statictable/2015/12/14/164/pendudukmenurut-jenis-kegiatan-utama-seminggu-yang-lalu-tahun-2014.html 